\title{
Biochemical, Morphologic, and Cytogenetic Studies of Leukocytes Growing in Continuous Culture from Normal Individuals and from Patients with Cystinosis
}

\author{
Josepil D. Schulman ${ }^{[59]}$, Kathrryn H. Bradley, Irene K. Berezesky, Philip M. Grimley, \\ W. Ediwin Dodson, and Matti S. Al-Aish
}

National Institute of Arthritis and Metabolic Diseases, the National Cancer Institute, and the National Institute of Child Health and Human Development, Bethesda, Maryland, USA

\section{Extract}

Continuous leukocyte cultures were established from the blood of three siblings with classical nephropathic cystinosis and from their mother. The cells from patients with cystinosis (CC) contained at least 15- to 20-fold more cystine than cultured leukocytes from normal individuals $(\mathrm{NC})$. The transport of cystine- ${ }^{35} \mathrm{~S}$ into $\mathrm{CG}$ was similar to uptake into $\mathrm{NG}$ when tested at $\mathrm{pH} 5.0$ and $\mathrm{pH} 7.4$.

The cultured CC could not be distinguished by ultrastructure from NC. Crystalline inclusions which could easily have been mistaken for cystine were observed in the lysosome of a normal cell. The modal number of chromosomes in CC and NC lines was 46 . There was a marked degree of aneuploidy. Tetraploidy was present in 3.8$9.6 \%$ of metaphases. Structural rearrangements and breaks were seen in all cell lines.

\section{Speculation}

Continuous leukocyte cultures may prove a useful experimental tool for further studies of the basic metabolic derangement responsible for abnormal intracellular accumulations of cystine in cystinotic cells (CC). The cultures are a convenient source of relatively large amounts of pure cellular material for investigative use. Because they grow in suspension, cultured leukocytes are well suited for investigation of transport phenomena in normal human cells (NC) as well as those with genetic diseases. The absence of a defect in the uptake of cystine at pH 5.0 in CC fails to support the hypothesis of a lysosomal transport abnormality for cystine in these cells, yet cannot be regarded as firm refutation of that hypothesis. Elucidation of the basic metabolic defect in cystinosis may require studies of the enzymology and transport systems of isolated lysosomes; such transport studies may have formidable technical problems.

The demonstration of intralysosomal crystals which could easily have been mistaken for cystine in one line of cultured NC emphasizes the need for great caution in assigning pathophysiologic significance to any rare crystalline bodies seen only in occasional lysosomes or other organelles of CC.

The chromosome abnormalities, and perhaps the capacity to proliferate, of continuously cultured leukocytes may be related to infection with herpes-like virus, as has been previously suggested. 


\section{Introduction}

Cystinosis is a recessively inherited autosomal clisease which in its characteristic nephropathic form results in the Fanconi syndrome and glomerular insufficiency during childhood with death in uremia before puberty $[5,44]$. Clinical variants of lesser severity have been recognized $[9,19,22,31]$. Cystinotic tissues contain large excesses of cystine, which are often visible in appropriately prepared tissues as intracellular crystalline deposits. Cystinotic white cells [35] and cultured fibroblasts $[37,38]$ contain increased intracellular cystine levels, and the metabolic defect responsible for cystinosis, which has so far eluded delineation, may be investigated in these cells. Considerable evidence suggests that cystinosis is a lysosomal storage clisease [21, $30,39-41,43,50]$.

Continuous suspension cultures of leukocytes may be derived from the peripheral blood of patients with lymphomas and leukemias and also from normal individuals $[4,15,18,26,32]$. The present report describes several of the properties of such cell lines cultured from normal individuals and those with cystinosis and illustrates the feasibility of utilizing these cells for investigations of the pathogenesis of cystinosis.

\section{Culture Technique}

Cell lines were developed by a modification of the method of Gerber and Monroc [18]. Peripheral blood, $50-100 \mathrm{ml}$, was drawn into $7.5-15 \mathrm{ml}$ commercially available acid-citrate-dextrose (ACD) anticoagulant solution (Fenwal) in a syringe prewarmed to $37^{\circ}$. The blood was transferred to $50-\mathrm{ml}$ plastic tulses [53] and allowed to sediment for 3-6 hr. The supernatant, including the interface region but with as few erythrocytes as possible, was removed and centrifuged at 400 $\times g$ for $10 \mathrm{~min}$. The cell pellet was washed once with prewarmed calcium-free phosphate-buffered saline, pII 7.4 , and resuspended in prewarmed medium [54] containing $20 \%$ fetal calf serum and $50 \mu \mathrm{g} / \mathrm{ml}$ neomycin in 8-ounce milk dilution bottles. Cell density was adjusted to $3-5 \times 10^{\prime 1} / \mathrm{ml}$ medium. The flasks were gassed with $95 \%$ air-5\% CO..., capped, placed on their sides, and incubated at $37^{\circ}$. During all manipulations caution was taken to avoid cooling the cultures to significantly below $37^{\circ}$.

Viable cell counts were obtained at intervals of several days using $0.1 \%$ solutions of trypan blue in $0.9 \%$ saline. The cultures were maintained at population densities of at least $5 \times 10^{5} / \mathrm{ml}$. To decrease the volume of medium as the cell number declined, the bottles were briefly centrifuged, and the supernatant me- dium was aspirated. When the medium in a culture became acid (as judged by the phenol red indicator) one-half of the spent medium was replaced with prewarmed fresh medium. If the cells in a culture became too lew for maintenance in the 8-ounce bottles, the cells were transferred to smaller cylindrical vessels and the "feecler layer" scraped from the side of the milk dilution bottle was included in the transfer; the milk dilution bottle with residual feeder layer was then refed with fresh medium and incubated without further disturbance as a reserve.

After 2-3 months, the small free floating cells in most cultures were replaced by a pleomorphic group of leukocytes in which large blastic cells were apparent. Usually, this was followed by an increase in cell number, increasing acidity of the medium, and appearance of grossly visible clumps in the culture. These occurrences signified the establislment of a proliferating cell line. In several cases, the successful culture was established in the reserve milk dilution bottle instead of the smaller bottle which had been tended more assiduously.

Once proliferating, the lines were grown easily by periodically feeding an equal volume of fresh medium acled to the spent acid medium one to two times per week. The population density in the cultures was approximately $0.3-1.2 \times 10^{6} \mathrm{cclls} / \mathrm{ml}$. Generation times were not determined precisely, but were about 2-5 days. Cultures were not continuously stirred or shaken. Larger batches were grown in cylindrical glass bottles, which were manually agitated every 1-2 days.

The cell lines were frozen in a viable state by modification of methods used for freezing cultured skin fibroblasts. The vehicle for freezing was RPMI 1640 containing $30 \%$ fetal calf serum and $10 \%$ dimethyl sulfoxide, and cell density was $10 \times 10^{6 /} / \mathrm{ml}$. The frozen vials were stored in liquid nitrogen tanks. For recovery, the vials were rapidly thawed, the medium containing the dimethyl sulfoxide (DMSO) was removed, and the cells were suspended in fresh medium [51].

We successfully established cell lines using the methods described above in five of six attempts. The three cystinotic lines (CC) were derived from the blood of three siblings with classical nephropathic cystinosis; the carrier line was from their mother; a normal line was from an unrelated normal adult (CS, Table II). Three additional normal cell (NC) lines also were used in this study [52]. All patients who were sources of successful cultures had a positive test for Epstein-Barr (herpes-like) virus antibody in their serum, as determined by Gerber and Monroe [18].

All cell lines were maintained in culture for over 6 
montlis, with no grossly detectable change in their properties.

\section{Intracellular Cystine Content}

\section{Method}

A technique modified from that of Schneider, Bradley and Seegmiller [35] was used. Cells were centrifuged at $400 \times g$ for 2 min and medium was aspirated. The cells were then alternately suspended and recentrifuged in three changes of phosphate-buffered saline at $4^{\circ}$. The final cell pellet was taken up in $1-2 \mathrm{ml}$ $1.5 \%$ sulfosalicylic acid and frozen until analysis. Cystine was determined on the protein-free supernatant with an amino acid analyzer [55] specially modified for high sensitivity, using the gradient elution system [10].

\section{Results}

The levels of cystine in three CC, one carrier, and three NC lines are shown in Table I. Cystinotic values fluctuated somewhat during the 6 months in culture, and the values in the table indicate the range after the cells were proliferating for at least 2 months. There was no trend toward a persistent alteration in the cystine levels during the culture period. The CC contained at least 15 - to 20 -fold more cystine than did the NC. The intracellular cystine level of the cell line cultured from the one obligate heterozygote for cystinosis was close to the control value.

\section{Transport Studies}

\section{Method}

The uptake of cystine-3is by CC and cultured NC was measured at $\mathrm{pH} 5.0$ and $\mathrm{pH} 7.4$ by modification of the technique of Clausen, Rodbell, and Dunand [8].

The cells in $200 \mathrm{ml}$ growth medium (population density $0.3-1.2 \times 10^{6} \mathrm{cells} / \mathrm{ml}$ ) were washed twice at $4^{\circ}$

Table I. Range of intracellular cystine content of continuous white cell lines

\begin{tabular}{ccc}
\hline Subjects & $\begin{array}{c}\text { Ialf-cystine, moles } \\
\times 101 / \mathrm{g} \text { cell protein }\end{array}$ & $\begin{array}{c}\text { Total protein/ } \\
\text { sample, mg }\end{array}$ \\
\hline Cystinosis type 1 & & \\
$I M I$ & $3.7-31.0$ & $4.40-13.0$ \\
$T M I$ & $4.0-5.4$ & $5.00-5.07$ \\
$L M I$ & $3.1-13.6$ & $2.57-8.43$ \\
Heterozygote & & \\
$R M I$ & $0.2-0.3$ & 11. \\
Normal & & \\
$X C$ & $0.2-0.3$ & 8.76 \\
$X G$ & $\leq 0.2-0.3$ & 5.00 \\
$C S$ & $\leq 0.2-0.3$ & 2.90 \\
\hline
\end{tabular}

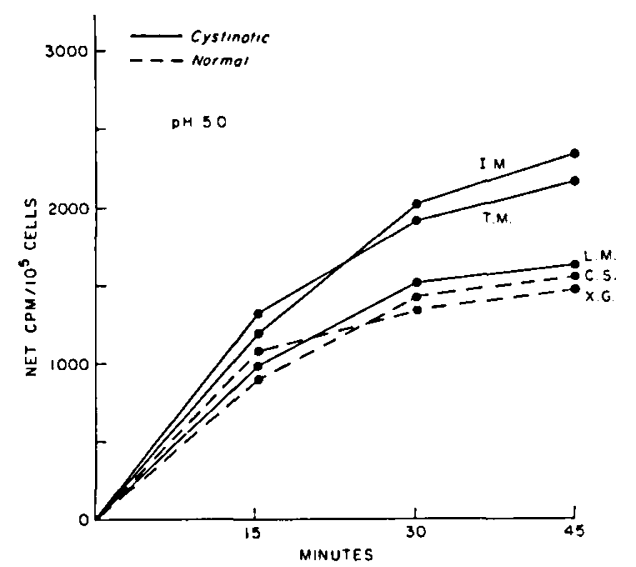

Fig. 1. Uptake of cystine-3*S by $\mathrm{CC}$ and cultured $\mathrm{NC}$ at $\mathrm{pH} 5.0$. See text for details.

in $10 \mathrm{ml} 0.9 \%$ saline with seclimentation at $100 \times g$ for $2 \mathrm{~min}$. Then $5-10 \times 10^{6}$ cells were incubated at $37^{\circ}$ in $3 \mathrm{ml}$ medium containing $\mathrm{MgCl}_{2}(2.5 \mathrm{~mm}), \mathrm{CaCl}_{2}$ (0.1 mM), KCl (10 mM), $\mathrm{NaCl}(130 \mathrm{~mm})$, bovine serum albumin (fatty acid-poor; $10 \mathrm{mg} / \mathrm{ml}$ ) [56], cystine_35 S (31.5 mCi/mmo'e, $0.28 \mathrm{~mm}$ ) [57], and $\mathrm{Na}$ phosphate (10 mM); final pH was adjusted to 5.0 or 7.4 with $\mathrm{HCl}$ or $\mathrm{NaOH}$.

At $0,15,30$, and $45 \mathrm{~min}$ triplicate $0.2-\mathrm{ml}$ aliquots were removed from each incubation tube and layered over $0.1 \mathrm{ml}$ ice-cold incubation mixture without cystine and albumin (wash fluid) in polyethylene microfuge tubes (Beckman). Cell pellets were prepared and counted as described [8] except for one additional wash. Viable cell counts were performed with $0.1 \%$ trypan blue at the beginning and end of the incubation. The cells remained viable during the $45-\mathrm{min}$ incubation period at either $\mathrm{pH}, 5.0$ (mean survival $103 \%$ ) or 7.4 (mean survival $96 \%$ ).

\section{Results}

Figures 1 and 2 show the uptake of radioactivity by CC and cultured NC incubated in medium containing cystine-35 $S$ at pH 5.0 and $\mathrm{pH} 7.4$; uptake is expressed as counts per minute above the zero time values per mean number of viable cells. Each point represents the average of triplicate determinations for each cell line.

At neither pH did CC show a diminished uptake when compared with control NC.

\section{Electron Microscopy}

\section{Methods}

Cell pellets were formed by centrifugation at $800-1,000 \times g$ for $5-10 \mathrm{~min}$. Pellets were fixed in 


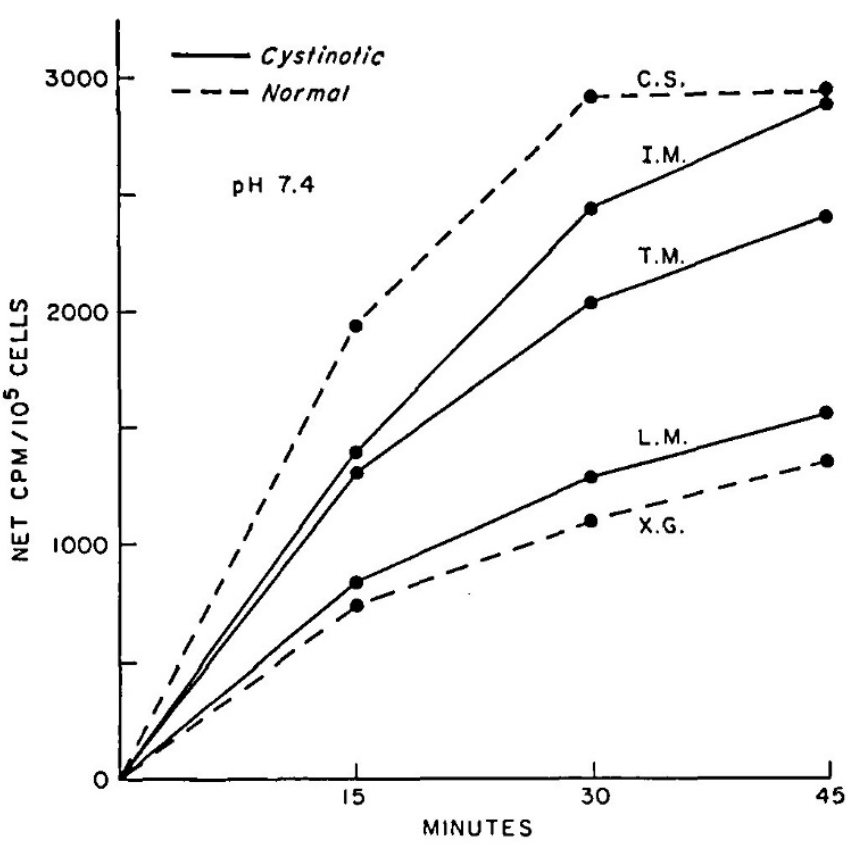

Fig. 2. Uptake of cystine-sts by CC and cultured NC at pH 7.4.

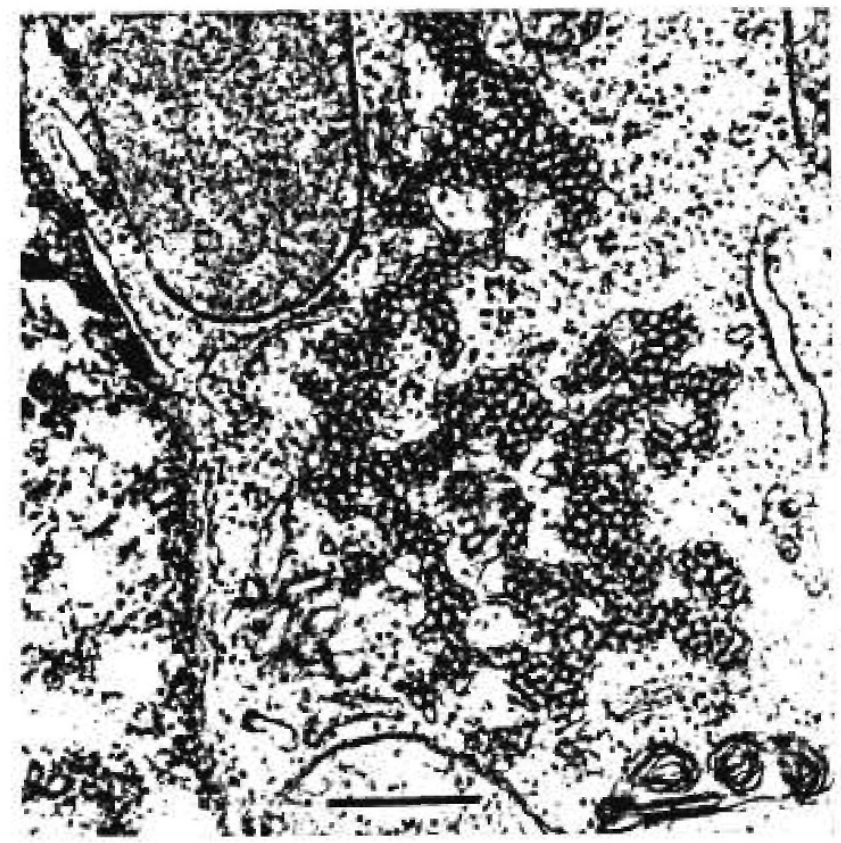

Fig. 3. Cultured lymphoid cell from a patient with cystinosis $(I M I)$. Electron-dense tubular structures form an elaborate network within dilated channels of the endoplasmic reticulum. $\times 32,000$.

2.5-3\% glutaraldehycle and prepared for electron $\mathrm{mi}-$ croscopy according to techniques previously reported $[2,3]$. Ultrathin epoxy sections were doubly stained with $5 \%$ uranyl acetate in methanol and with satu- rated lead citrate [49], before examination in an electron microscope [58].

\section{Results}

All white cell lines showed similar ultrastructural features and could not be distinguished qualitatively either from each other or from cells of previously described lymphoid cell lines $[2,13,26,28]$. A spectrum of lymphoreticular cells was observed in cach culture sample, although the predominant cell would be described as "blast-like" [13] with sparse granular endoplasmic reticulum, prominent Golgi zones, and moderate numbers of mitochondria. In the lines presently examined, plasmocytic type cells and large histiocytic cells [2] were not common. One of the control cultures but none of the cystinotic samples contained cells with herpes type intranuclear virus particles (EB virus). Dense microtubular structures (Fig. 3) within the endoplasmic reticulum, previously described in lymphoid cell lines of neoplastic and nonneoplastic origin $[3,6$, $12,26,28]$, were abundant in cells of two patients with cystinosis and in one of the controls. Enlarged mitochondria with paracrystalline inclusions (Fig. 4) were seen in occasional cells of the cystinotic cultures and resembled mitochondrial inclusions previously described in lymphoma cells [3]. An active Golgi apparatus was common in all of the cells examined, and

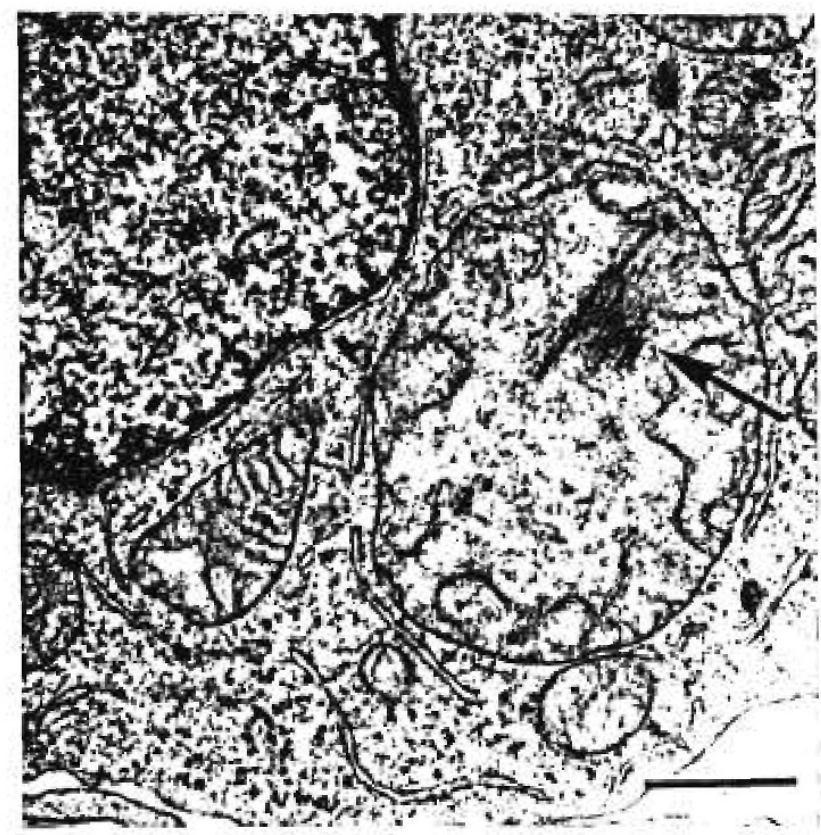

Fig. 4. Cultured lymphoid cell from patient with cystinosis $(I M I)$. Enlarged mitochondrion contains a paracrystalline inclusion (arrow). $\times 32,000$. 
many cells contained heterogeneous dense structures which would be classified as lysosomes. Many of these lysosomes contained fragments of membrane or other debris which could have been cellular in origin (Fig. 5). Numbers of lysosomal bodies varied within each sample, but appeared as numerous as in some previously studied lymphoid cell lines [2, 12, 13]. Curiously, hollow lancellate structures which might easily have been interpreted as cystine crystals were they present in a CC line were identified in one lysosome of a control culture (Fig. 6).

\section{Cytogenetics}

\section{Method}

Two CC, one carrier, and four continuous NC lines, all approximately 6 months old, were examined cytogenetically [1].

\section{Results}

The modal number of chromosomes in all lines was 46 (1iig. 7). There was a marked degree of aneuploidy and an increased frequency of tetraploidy in all lines examined (Table II). Tetraploidy was present in from $3.8-9.6 \%$ of the metaphases (Fig. 8). In all lines the frequency of hypodiploidy was greater than hyperdiploidy. In the hypodiploid lines, chromosome loss was

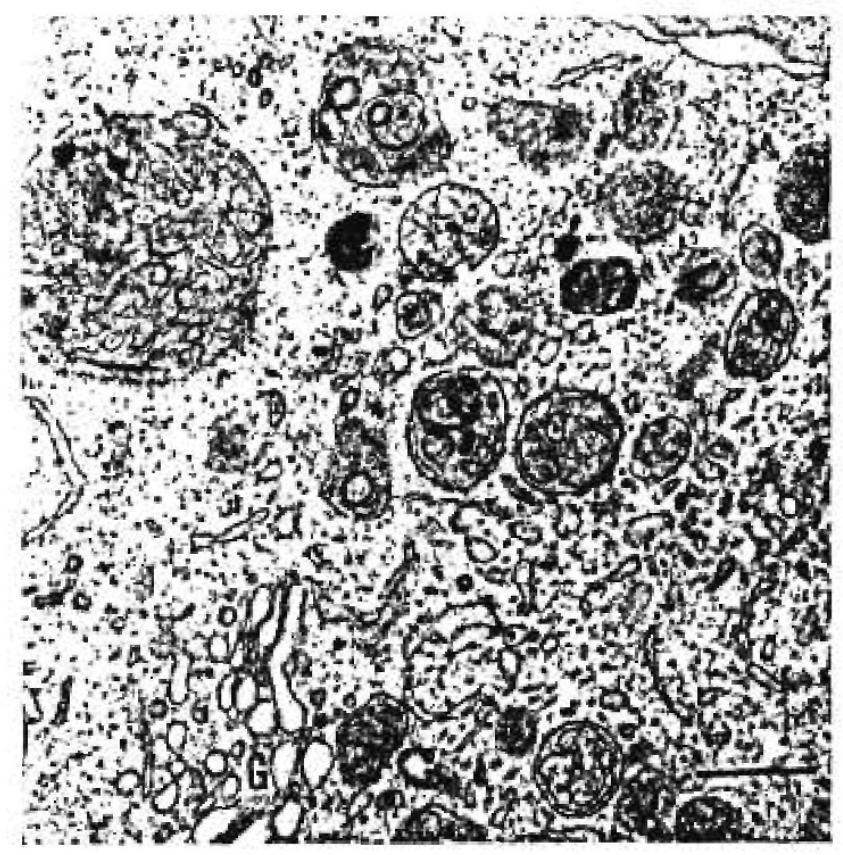

Fig. 5. Culture lymphoid cell from cystinosis carrier (RM) Cluster of lysosomal bodies with membranous inclusions located in the region of the Golgi apparatus $(G) . \times 26,000$.

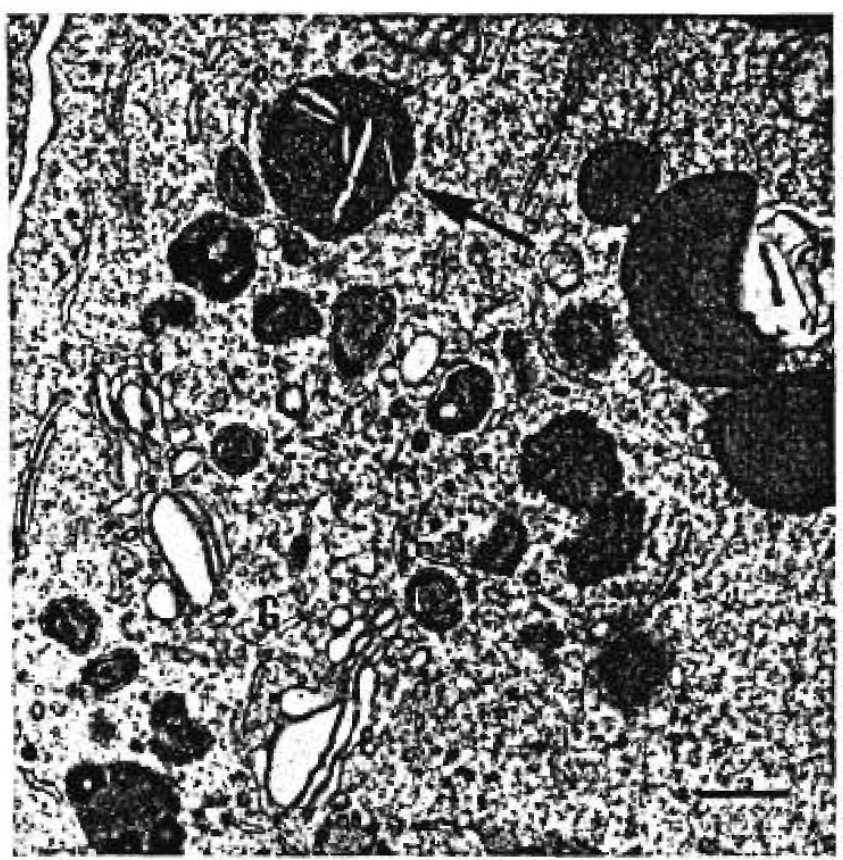

Fig. 6. Cultured lymphoid cell from a healthy control (CS). Dense lysosomal bodies are typically clustered in the Golgi region (G). One body (arrow) contains hollow inclusions resembling crystals. Bar equals $0.5 \mu$.

random and no clearly defined clones were recognized. The majority of those missing, however, were from G, F, or E groups. Structural rearrangements and breaks were seen in both CC and NC lines (Fig. 9). No clear markers were apparent, although one normal subject $(C)$ had a ring chromosome from the $\mathrm{C}$ group present in $6 \%$ of his cells.

\section{Discussion}

The present study indicates that leukocyte lines from individuals with cystinosis, maintained for some months in culture, expressed and maintained expression of the increased intracellular cystine content which was the biochemical characteristic of cystinotic cells. This has been demonstrated previously for cystinotic fibroblasts in culture [37, 38]. The cystine levels in the cultured CC were somewhat lower than the levels found in the fibroblasts [37] or in peripheral CC (uncultured) [35]. Differences in the intensity of crystal cleposition in cystinotic organs have been appreciated for many years, and different classes of cystinotic peripheral white cells have different cystine levels [42]. Leukocyte cell lines are more difficult to establish than fibroblast cultures, but once proliferation begins they are much easier to maintain and more easily grown for study, and, unlike fibroblasts, these cells may probably 


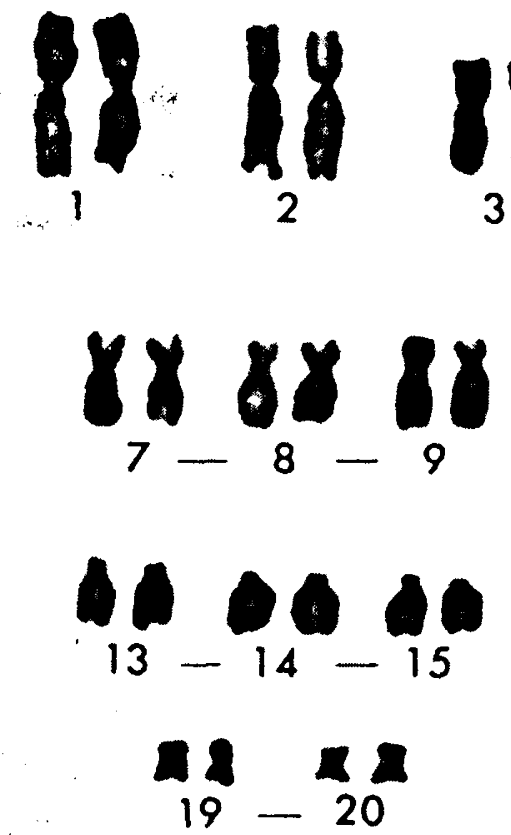

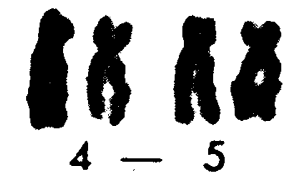
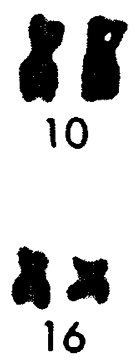

Y
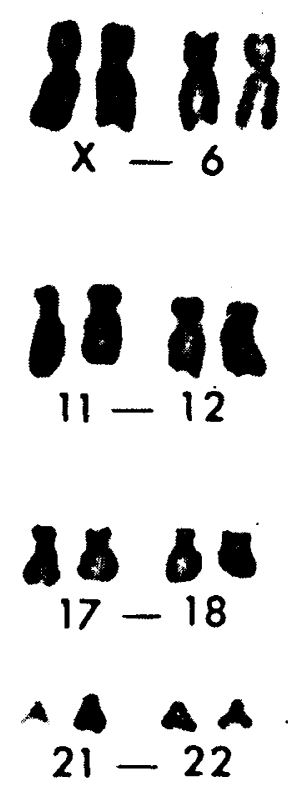

Fig. 7. Karyotype of normal continuous lymphocyte line derived from subject CS. Chromosomes were arranged according to $\mathrm{Al}-\mathrm{\Lambda}$ ish [1.]

Table II. Cytogenetic findings in long-term leukocyte cultures from cystinosis, carrier, and normal subjects

\begin{tabular}{|c|c|c|c|c|c|c|c|c|c|c|c|c|c|c|c|c|}
\hline \multirow[b]{2}{*}{ Subject } & \multirow[b]{2}{*}{ Sex } & \multirow[b]{2}{*}{ Condition } & \multicolumn{6}{|c|}{ No. of chromssomes } & \multirow{2}{*}{$\begin{array}{l}\text { Total } \\
\text { cells } \\
\text { counted }\end{array}$} & \multicolumn{6}{|c|}{ Structural alterations } & \multirow[b]{2}{*}{ Comment } \\
\hline & & & $<45$ & 45 & 46 & $+(6-9) 1$ & 92 & $\begin{array}{l}\text { Endo- } \\
\text { mitosis }\end{array}$ & & Gap & Breaks & $\begin{array}{l}\text { Frag- } \\
\text { ment }\end{array}$ & $\begin{array}{c}\text { Dicen- } \\
\text { tric }\end{array}$ & Ring & $\begin{array}{c}\text { Trira- } \\
\text { dius }\end{array}$ & \\
\hline$T M$ & $\mathrm{~F}$ & Cy'stinosis & 3 & 6 & 56 & 3 & 5 & & 73 & 3 & 2 & & 1 & 1 & & \\
\hline$I M$ & $\mathbf{M}$ & Cystinosis & 6 & 4 & 36 & & 3 & 1 & 50 & & 1 & 1 & 1 & & & \\
\hline$R$ & $F$ & Carrier & 7 & 6 & 33 & 1 & 5 & & 52 & & 2 & & & & & \\
\hline$C S$ & $F$ & Normal & 65 & 44 & 350 & 7 & 37 & & 503 & 8 & 13 & 46 & 7 & & 1 & \\
\hline$G$ & $\mathbf{M}$ & Normal & 10 & 7 & 31 & 3 & 2 & & 53 & & 2 & 1 & 1 & & & \\
\hline$C$ & $\mathbf{M}$ & Normal & 9 & 5 & 23 & 1 & 3 & & 51 & & 1 & 2 & & 3 & & $\begin{array}{l}\text { All rings in } \\
\text { C grousp }\end{array}$ \\
\hline$E$ & $M$ & Niurmal & 9 & 8 & 31 & & 1 & 1 & 50 & 1 & 1 & 2 & & & & \\
\hline
\end{tabular}

be indefinitely maintained in culture. The cultured white cells have been used for enzymologic studies of cystinosis which will be reported elsewhere [48]. The present study highlights certain other properties of these cells including the facility with which they may be used to investigate transport phenomena.

Uncultured cystinotic white cells are not deficient in activity of the mechanism for cysteine transport across the outer cell membrane [36]. There is good evidence that cysteine and cystine have different transport systems in peripheral white cells [36] (where cystine uptake is relatively poor [33]), rat kidney cortex [45], and lower organisms [46]. Cultured leukocytes have adapted to an extracellular source of cystine which is entirely in disulfide form in the culture medium. The normal uptake of cystine by CC at physiologic $\mathrm{pH}$ (7.4) was not surprising and was consonant with the normal growth rate of $\mathrm{CC}$ in culture, where cystine is an essential amino acid [14, 17].

The uptake studies at $\mathrm{pH} 5.0$ represented an attempt to examine indirectly a possible transport system for cystine which might be operative at the level of the lysosomal membrane. Cystinosis appears to be a lysosomal cystine storage cliscase [21, 30, 39-41, 43, 50], and an abnormality in a membrane permease facilitating the efflux of cystine from the lysosomes could account for such storage. The interior $\mathrm{pH}$ of the lysosome is regarded as considerably more acid than the rest of the cell cytoplasm or extracellular fluid [23]. Furthermore, the membranes of at least certain kinds of lysosomes are in part derived from the cell membrane through invagination of the surface membrane. The inside of the membrane of vacuoles so formed is homologous with the outside of the cell membrane 


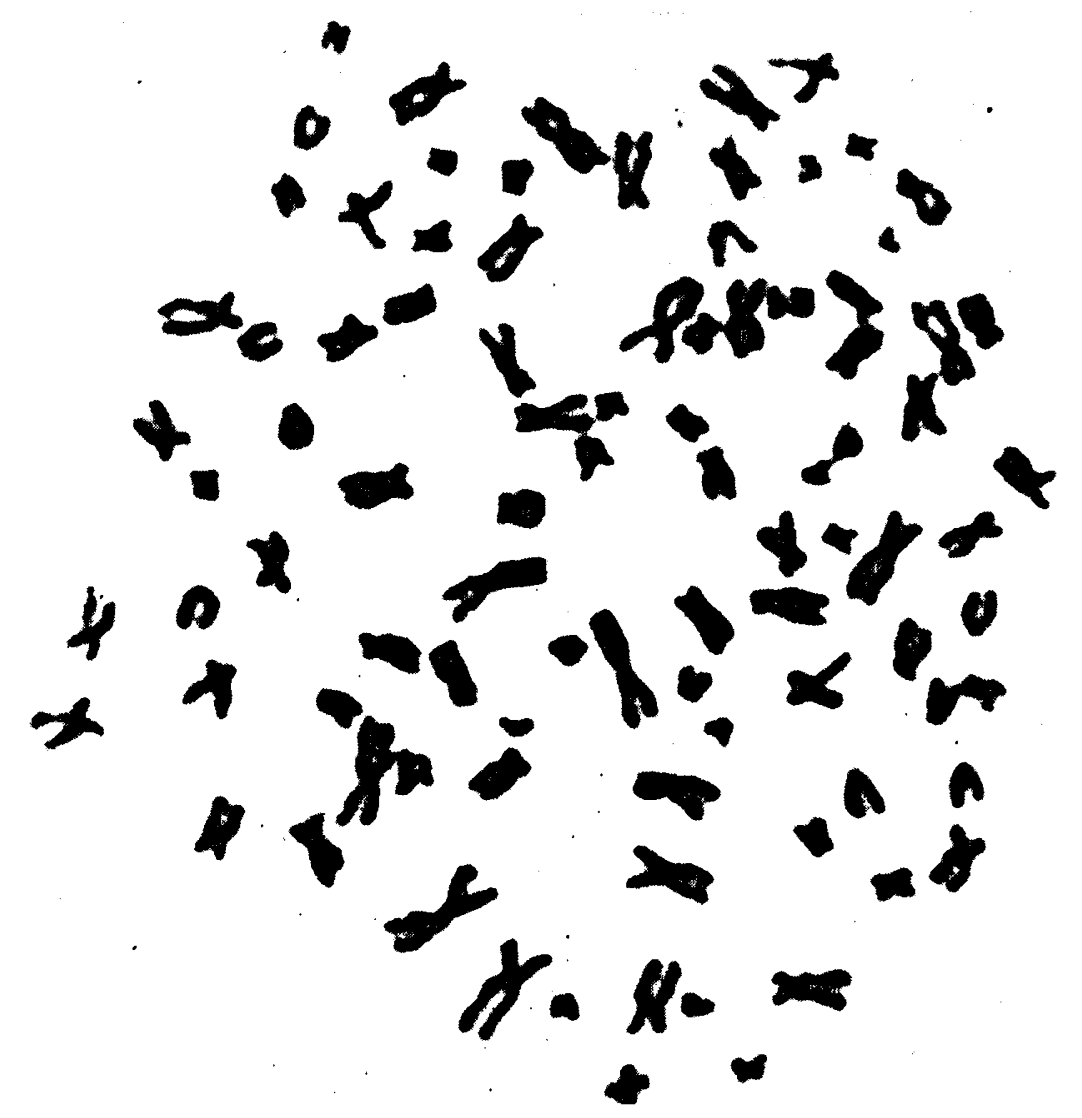

Fig. 8. A tetraploid metaphase from subject CS showing 92 distinct chromosomes.

[23]; the compositions of both membranes are similar [47]. We reasoned, therefore, that measurement of cystine movement across the outer cell membrane from outside to inside at acid $\mathrm{pH}$ might indicate the activity of a system which facilitates the eflux of cystine from lysosomes.

The uptake of cystine at acid pH into CG did not appear deficient in this study. No further attempt was made to define whether uptake proceeded by active transport or other mechanism. Although the results failed to support the hypothesis of a lysosomal membrane abnormality in cystinosis, because of the assumptions involved they did not rule out this possibility.

The cultured white cells from patients with cystinosis could not be distinguished by ultrastructure from cells derived from normal individuals, despite biochemical evidence of consistently higher intracellular quantities of cystinc. Similar findings have been observed in cystinotic fibroblasts [20], although other observers have described what they regard as characteristic alterations but no crystal formation in cystinotic fibroblast lysosomes [43]. Presumably, in the cultured leukocytes, the excess cystine was sequestered within lysosomes, but crystalline structures, which might have provided a morphologic marker, were not observed by us. The limited sampling power of the electron microscope cloes not permit us to exclude that rare cystine crystal might conclense in an occasional CC; however, this was certainly not the pattern observed in the several hundred cell sections which were examined. The presence of crystalline inclusions, which could easily have been mistaken for cystine crystals in a lysosome of a normal cell, indicates the need for extreme caution in drawing conclusions about the pathophysiologic significance of rare crystals that might be found in those CC where crystal deposition is not prominent. Intralysosomal membrane fragments of the same appearance as those experimentally induced by chloroquine [16] were found in CG and non-CC, and appeared to represent evidence of autophagy [11] by the lysosomes.

The mitochondrial matrix fibrils observed in the cultured leukocytes might conceivably be misinterpreted as cystine. This is not a moot point, in view of one report that crystals have been observed within ap- 


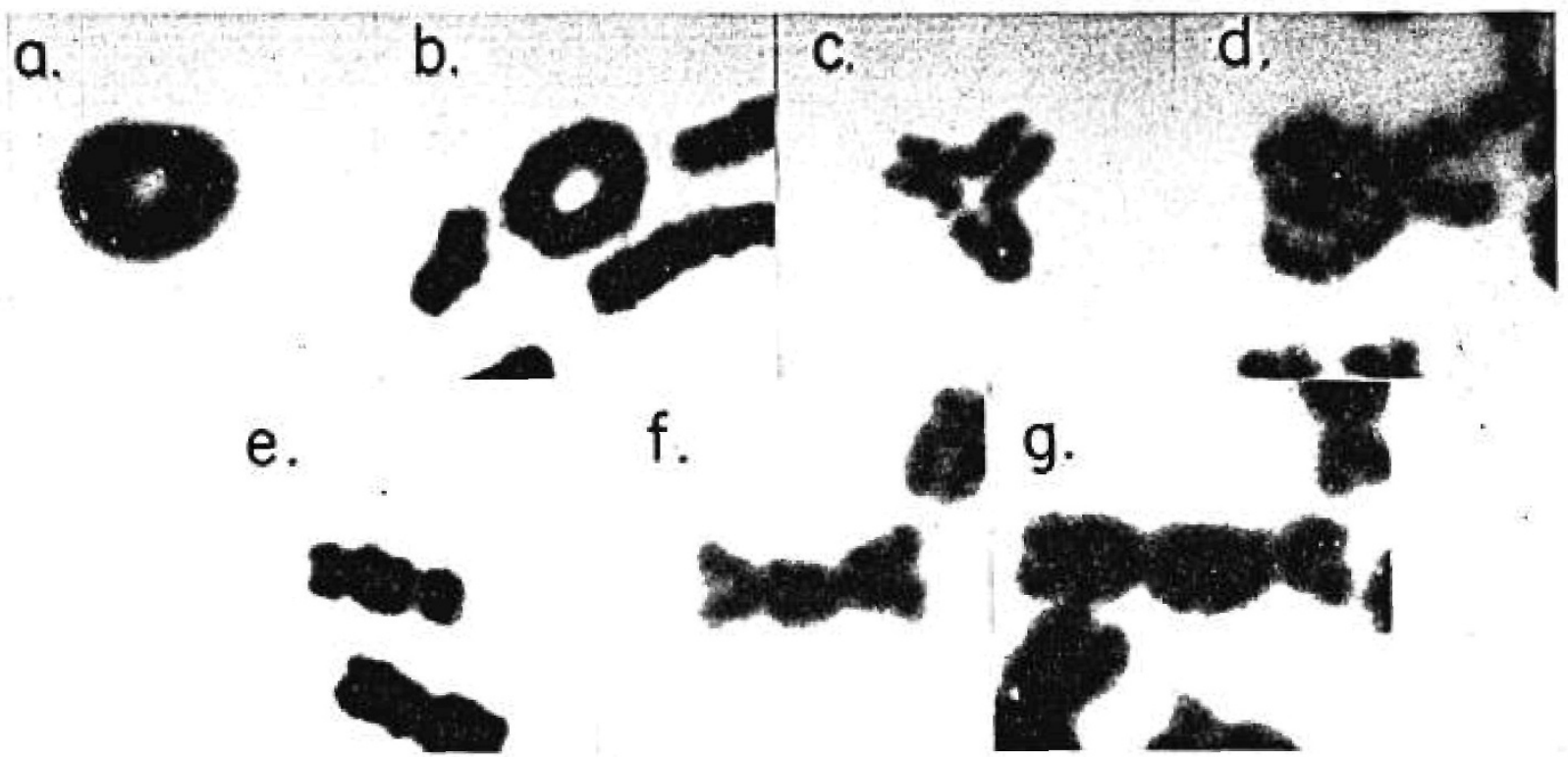

Fig. 9. Structural rearrangements and alterations. $a$ and $b$ : Ring C. $c$ : Triradius. $d$ : Unusual secondary association ("pregnant chromosome") $e, f$, and $g$ : Dicentric chromosomes.

parent mitochondria in an intestinal biopsy from a case of cystinosis [27]. The exact nature of the crystals that we observed in the mitochondria is unknown, but may represent mitochondrial deoxyribonucleic acid (DNA) [3] or crystallized mitochondrial enzymes [34].

Patients with Fanconi's syndrome of renal tubular dysfunction, with or without cystinosis, have not bcen reported to have chromosome breakage in short-term lymphocyte cultures. In continuous cultures, CC showed no significant cytogenetic differences from those of NC. All lines have diploid modal counts. Within the lines, hypodiploidy and tetraploidy were the most frequently observed variants from the modal numbers, a pattern previously noted in long-term leukocyte lines $[7,25]$.

Breaks and structural rearrangements were prevalent in all lines. Viruses are recognized to cause chromosomal breaks in vivo and in vitro [24, 29]. The presence of antibodies to herpes-like virus was noted in clonors of our established long-term leukocyte lines, and virus particles similar to those observed in four of six lines by Gerber and Monroe [18] were seen in one of our lines. Thus, it is possible that the breaks and structural rearrangements observed here might be related to the presence of virus.

\section{Summary}

Leukocytes growing in continuous culture have been derived from normal individuals and subjects homozy- gous and heterozygous for nephropathic cystinosis. The cultured leukocytes from patients with cystinosis have abnormally elevated levels of nonprotein cystine. Distinctive morphologic abnormalities were not found in the cystinotic cells by electron microscopy. All cell lines had a primarily diploid chromosome complement, although hypodiploidy, tetraploidy, and other chromosome abnormalities were observed. The cystinotic cells showed no defect in the uptake of exogenously supplied cystine ${ }^{3 \check{S}} \mathrm{~S}$ either at neutral or at acid $\mathrm{pH}$.

\section{References and Noles}

1. At-Aisu, M.: Human chromosome morphology. I. Studies on normal chromosome characterization, classification, classification and karyotyping. Can. J. Genet. Cytol., 11: 370 (1969).

2. Bedoya, V., Grimley, P., AND Rabson, A.: Ultrastructural evidence of in vitro interaction among Burkitt lymphoma cells: possible relevance to the "phagocytic" activity of starry sky histiocytes in vivo. Cancer Res., 29: 753 (1969).

3. Bedoya, V., Rarson, A., ANd Grimley, P.: Growth in vitro of herpes simplex virus in human lymphoma cell lines. J. Nat. Cancer Inst., f1: 635 (1968).

4. Benyeshi-Melnick, M., Phillips, G., Lewis, R., and Seidel, E.: Studies in acute leukemia and infectious mononucleosis of childhood. IV. Continuous propagation of lymphoblastoid cells from spontancously transformed bone marrow cultures. J. Nat. Cancer Inst., 40: 123 (1968).

5. Bickel, H., Smallwood, W., Smelle, J., BaAr, H., Hickmans, E., Harris, H., Astley, R., Teall, C., Douglas, A., Philfott, M., Harvery, C., ANd Finch, E.: Cystine storage disease with aminoaciduria and dwarfism (Lignac-Fanconi disease). Acta Paediat. 42: Suppl. 90, 1 (1952). 
6. CHANDRA, S.: Undulating tubules associated with endoplasmic reticulum in pathologic tissues. Lab. Invest., 18: 422 (1968).

7. Christofinis, G.: Chromosome and transplantation results of a human leukocyte cell line derived from a healthy individual. Cancer, 24: 649 (1969).

8. Clausfin, T., Rodbell, M., and Dunand, P.: The metabolism of isolated fat cells. J. Biol. Chem., 2f4: 1252 (1969).

9. Cogan, D., Kuwabara, T., Kinoshita, J., Sheehan, L., and MerolA, L.: Cystinosis in an adult. J. A. M. A., 164: 394 (1957).

10. Crawhile, J., Thompson, G., and Bradiey, K.: Separation of cystine, penicillamine disulfide, and cysteinine-penicillamine mixed disulfide by automatic amino acid analysis. Anal. Biochem., 14: 405 (1966).

11. DEDuve, C.: The lysosome in retrospect. In: J. Dingle and $\mathrm{H}$. Fell: Lysosomes in Biology and Pathology, Vol. 1, p. 3 (American Elsevier, New York, 1969).

12. Douglas, S. D., Blume, R., Glade, C., Chessin, L., and WolfF, S.: Fine structure of continuous long term lymphoid cell cultures from a Chediak-Higashi patient and heterozygote. Lab. Invest., 21: 225 (1969).

13. Douglas, S., Borjeson, J., and Chessin, L.: Studies on human lymphocytes in vitro. IV. Comparative fine structural features of the cstablished Burkitt lymphoma cell lines AL1, EB2 and phytomitogen-transformed lymphocytes. J. Immunol., 99: 340 $(1967)$.

14. Eagle, II., Washington, C., and Frifdian, S.: The synthesis of homocystine, cystathionine, and cystine by cultured diploid and heteroploid human cells. Proc. Nat. Acad. Sci. U. S. A., 56: 156 (1966).

15. Ei'steIN, M., AND BARR, Y.: Characteristics and mode of growth of a tissuc culture strain (EB1) of human lymphoblasts from Burkett's lymphoma. J. Nat. Cancer Inst., 3t: 231 (1965).

16. FfDorko, M.: Effects of chloroquine on morphology of leukocytes and pancreatic exocrine cells from the rat. Lab. Invest., $1 s: 27$ (1968).

17. Foley, G., Barell, E., Apans, R., and Lazarus, H.: Nutritional requirements of human leukemic cells. Cystine requirements of diploid cell lines and their heteroploid variants. Exp. Cell Res., 57: 129 (1969).

18. Gerber, P., ANd Monroe, J.: Studies in leukocytes growing in continuous culture derived from normal human donors. J. Nat. Cancer Inst., 40: 855 (1968).

19. Goldman, H., Scriver, C., Aaron, K., and Pinsky, L.: Use of dithiothreitol to correct cystine storage in culture cystinotic fibroblasts. Lancet, $i: 811$ (1970.)

20. Grinley, P., Schulman, J., and Seegmiller, J.: Unpublished observations.

21. Hummeler, K., Zajac, B., Genel, M., Holtzapple, P., and Srgat, S.: Human cytinosis: intracellular deposition of cystinc. Science, 168: 859 (1970).

22. Lietman, P., Frazier, P., Wong, V., Shotton, D., and SeegmilLF., J.: Adult cystinosis-a benign disorder. Amer. J. Med., 40: $511(1966)$.

23. Lucr, J.: Lysosomal membranes. In: J. Dingle and H. Fell: Lysosomes in Biology and Pathology, Vol. 2, p. 313 (American Elsevier, New York, 1969).

24. Makino, S., ANd Aya, T.: Cytogenetic studies in leukocyte cultures from patients with some viral diseases and in those infected with HSV. Cytologia, 33: 370 (1968).
25. Miles, G., O'Neill, F., Armstrong, D., Clarkson, B., And KEANE, J.: Chromosome patterns of human leukocyte established cell lines. Cancer Res., 28: 481 (1968).

26. Moore, G., Kitamura, H., and Toshima, S.: Morphology of cultured hematopoictic cells. Cancer, 22: 245 (1968).

27. Morf.,ki, R., Paunier, L., and Hamilton, J.: Intestinal mucosa in cystinosis. A fine structure study. Arch. Pathol., 86: 297 (1968).

28. Moses, H., Glade, P., Kasel, J., Rosenthal, A., Hirsihaut, Y., AND Cilessin, L: Infectious mononucleosis, detection of herpeslike virus and reticular aggregates of small cytoplasmic particles in continuous lymphoid cell lines derived from peripheral blood. Proc. Nat. Acad. Sci. U. S. A., 60: 489 (1968).

29. Nichols W., Hat.L, B., and Ostergren, G.: Measles associated with chromosome breakage. Hereditas, 48: 367 (1962).

30. Patrick, A., and Lake, B.: Cystinosis: clectron microscopic evidence of cystine storage in lymph node. J. Clin. Path., 21: 571 (1968).

31. Pittman, G., and Schulman, J.: In preparation.

32. Rabson, A., O'Conor, G., Baron, S., Whang, J., and LegalLAIS, F.: Morphologic, cytogenetic, and virologic studies in vitro of a malignant lymphoma from an African child. Int. J. Cancer, 1: 89 (1966).

33. Roseniberg, L., and Downing, S.: Transport of neutral and dibasic amino acids by human leukocytes: absence of a defect in cystinuria. J. Clin. Invest., 44: 1382 (1965).

34. RuFfolo, R., AND Covington, H.: Matrix inclusion bodies in the mitochondria of human liver. Amer. J. Pathol., 51: 101 (1967).

35. Schneider, J., Bradley, K., and Sefg.itlleer, J.: Increased cystine in leukocytes from individuals homozygous and heterozygous for cystinosis. Science, 157: 1321 (1967).

36. Schineiner, J., Brablfy, K., And Srficilleter, J.: Transport and intracellular fate of cysteine ${ }^{-3 r} S$ in leukocytes from normal subjects and patients with cystinosis. Pediat. Res., 2: 441 (1968).

37. Schineider, J., Rosenbloom, F., Bradley, K., and Seegmiller, J.: Increased free-cystine content of filsroblasts cultured from patients with cystinosis. Biochem. Biophys. Res. Commun., 29: 527 (1967).

38. Schineidfr, J., Wong, V., Bradiey, K., ANd Sefgmiller, J.: Biochemical comparison of the adult and childhood forms of cystinosis. New Engl. J. Med., 279: 1253 (1968).

39. Scilulaian, J., AND Bradley, K.: Cystinosis: selective induction of vacuolation in fibroblasts by L-cysteine-D-penicillamine disulfide. Science, 169: 595 (1970).

40. SCHulman, J., AND BRADLEY, K.: The metabolism of amino acids, peptides and disulficles in lysosomes of fibroblasts cultured from normal man and individuals with cystinosis. J. Exp. Med., 132: 1090 (1970).

41. Scibuman, J., Braitfy, K., and Seegmileer, J.: Cystine: compartmentalization within lysosomes in cystinotic leukocytes. Science, 166: 1152 (1969).

42. Schulman, J., Wong, V., Kuwabara, T., Bradley, K., and SeEgmiller, J.: Intracellular cystine content of leukocyte populations in cystinosis. Arch. Intern. Med., 125: 660 (1970).

43. Schulman, J., Wong, V., Olson, W., aNd Seegmilt.fr, J.: Lysosomal site of crystalline deposits in cystinosis as shown by ferritin uptake. Arch. Pathol., 90: 259 (1970).

44. Seegmiller, J., Friedmand, T., Harrison, H., Wong, V., and SCHNFJder, J.: Cystinosis. Ann. Intern. Medl., 68: 883 (1968). 
45. Segal, S., aNd Crawiull, J.: Characteristics of cystine and cysteine transport in rat kidney cortex slices. Proc. Nat. Acad. Sci. U. S. A., 59: 231 (1968).

46. SKYE, G., AND SEGEL, I.: Independent regulation of cysteine and cystine transport in penicillum chrysogenum. Arch. Biochem. Biophys., 138: 306 (1970).

47. Thines-Sempoux, D.: Chemical similarities between the lysosome and plasma membranes. Biochem. J., 105: 20P (1967).

48. Tietze, F., Bradley, K., and Schulman, J.: Pediat. Res., (in press $>$.

49. Venable, J., and Coggeshell, R.: A simplified lead citrate stain for use in electron microscopy. J. Cell. Biol., 25: 407 (1965).

50. Wong, V., Kuwabara, R., Brubaker, R., Olson, W., Schul- man, J., AND Seegmillefer, J.: Intralysosomal cystine crystals in cystinosis. Invest. Opthalmol., 9: 83 (1970).

51. This freczing technique was suggested by Dr. Paul Gerber.

52. A generous gift of Dr. Paul Gerber.

53. Falcon Plastics, Division of BioQUEST, Cockeysville, Md.

54. RPMI 1640 medium, NIH Media Division, Bethesda, Md.

55. Nodel 120B, Beckman Instruments, Palo Alto, Calif.

56. Mann Research Laboratories, New York, N. Y.

57. Amersham-Searle, Des Plains, Ill.

58. Model Hul 1-E, Perkin-EImer Hitachi, Norwalk, Conn.

59. Requests for reprints should be addressed to: JoserH $D$. Sciulman, M.D., National Institute of Arthritis and Metabolic Discases, National Institutes of Health, Bethesda, Md. 20014 (USA).

60. Accepted for publication November 18, 1970. 